\title{
A novel salt-tolerant strain Trichoderma atroviride HN082102.1 isolated from marine habitat alleviates salt stress and diminishes cucumber root rot caused by Fusarium oxysporum
}

Chongyuan Zhang ${ }^{1 \dagger}$, Weiwei Wang ${ }^{2,3+}$, Yihui Hu' , Zhongpin Peng ${ }^{1}$, Sen Ren ${ }^{1,4}$, Ming Xue ${ }^{1,4}$, Zhen Liu', Jumei Hou', Mengyu Xing ${ }^{1}$ and Tong Liu ${ }^{1,4^{*}}$

\begin{abstract}
Background: Salt stress threaten the growth of plants, and even aggravate plant disease. In this article, salt-tolerant Trichoderma strain was isolated, and its potential to alleviate salt stress and diminish cucumber root rot caused by Fusarium oxysporum was evaluated.

Results: Twenty-seven Trichoderma isolates were isolated from samples of sea muds and algae collected from the South Sea of China. Among these, the isolate HN082102.1 showed the most excellent salt tolerance and antagonistic activity against $F$. oxysporum causing root rot in cucumber and was identified as T. atroviride. Its antagonism ability may be due to mycoparasitism and inhibition effect of volatile substances. The application of Trichoderma mitigated the adverse effects of salt stress and promoted the growth of cucumber under $100 \mathrm{mM}$ and $200 \mathrm{mM} \mathrm{NaCl}$, especially for the root. When T. atroviride HN082102.1 was applied, root fresh weights increased by 92.55 and $84.86 \%$, respectively, and root dry weights increased by 75.71 and $53.31 \%$, respectively. Meanwhile, the application of HN082102.1 reduced the disease index of cucumber root rot by 63.64 and $71.01 \%$ under 100- and 0-mM saline conditions, respectively, indicating that this isolate could inhibit cucumber root rot under salt stress.

Conclusions: This is the first report of salt-tolerant T. atroviride isolated from marine habitat showing antagonistic activity to F. oxysporum, and the results provide evidence for the novel strain T. atroviride HN082102.1 in alleviating salt stress and diminishing cucumber root rot, indicating that T. atroviride strain HN082102.1 can be used as biological control agent in saline alkali land.
\end{abstract}

Keywords: Biological control, Cucumber root rot, Growth promotion, Salt stress, Trichoderma atroviride

*Correspondence: liutongamy@sina.com

${ }^{\dagger}$ Chongyuan Zhang and Weiwei Wang contributed equally to this work.

${ }^{4}$ Engineering Centre of Agricultural Microbial Preparation Research

and Development of Hainan, Hainan University, Haikou, Hainan 570228,

PR China

Full list of author information is available at the end of the article

\section{Background}

Salt stress affects almost every aspect of the physiology and biochemistry of plants, thereby limiting plant growth and productivity [1], and even the morphological development of individual plant [2]. Under salt stress, the accumulation of $\mathrm{Na}^{+}$and $\mathrm{Cl}^{-}$in cells significantly decreases the content of glycolipids and 
unsaturated fatty acids, increases the content of saturated fatty acids in the thylakoid membrane, and inhibits the activity of photosynthesis-related enzymes such as Rubisco and PEP carboxylase, thereby disrupting the photosynthetic capacity [3]. Also, reactive oxygen species (ROS) showing strong oxidation ability accumulates, and damages unsaturated fats, proteins, nucleic acids, and other biomolecules [4]. What's more, salt stress exacerbates the degree of membrane lipid peroxidation, leading to the destruction of membrane integrity, massive leakage of electrolytes and some small organic molecules, and disruption of the material exchange balance within cell [5]. Therefore, salt stress makes plants more vulnerable to a variety of threats including pathogens. Many studies have reported that salt stress can aggravate the effects of pathogenic diseases on plants, such as Phytophthora capsica [6], Fusarium oxysporum [7], Alternaria solani [8], and so on. In China, there is about $2.6 \times 10^{7}$ ha of saline-alkali land [9]. The salt content of saline-alkali land is greater than $0.6 \%$, and it is difficult for plants to grow on this type of land. Therefore, it is important to improve the utilization of saline-alkali soil in order to increase cultivated land area and ensure ecological security.

Root rot caused by F. oxysporum is an important soilborne disease in cucumber. Various control methods are used to avoid losses in cucumber yield due to root rot. Physical methods such as sunlight or ultraviolet radiation [10] and chemical methods [11] are commonly used. Although the chemical fungicides are very effective in controlling plant fungal diseases, they also bring many problems, such as the fungicide-resistance of pathogens and the ecological security [12]. So, researchers are now trying to use environmentally safe methods to control root rot, such as biological agents [13].

Trichoderma species are widely distributed in nature worldwide, and have been successfully used as biofertilizers, biopesticides and bioremediation agents $[14,15]$. It is reported that Trichoderma played an important role in reducing the adverse effects of salt stress in the desert shrub Ochradenus baccatus [16]. Trichoderma can be used to control plant disease mainly due to their antagonistic and mycoparasitic activity [17-19]. Also, they can enhance nutrients absorption of plant [20] and promote the production of numerous biochemical elicitors, including all kinds of peroxidases (PODs), chitinase, $\beta$-1,3-glucanase, lipoxygenase-pathway hydroperoxide lyase, and compounds such as phytoalexins and phenols, thereby promoting growth and enhancing biotic and abiotic stress tolerance of plants [21-23]. So, the aim of the present study was to determine whether Trichoderma could alleviate the negative effects of salt stress and diminish root rot in cucumber.

\section{Methods}

\section{Identification of the pathogen of cucumber root rot}

Diseased cucumber plants with typical symptoms of root rot or damping-off (rotted roots, wilted leaves, leaves cannot be spread normally, leaf tip chlorosis) were collected from cucumber fields in Hainan province, immediately placed into plastic bags and stored in iceboxes. The pathogenic fungus was isolated by the tissue separation method, and the pathogenicity of the purified fungus was determined according to Koch's postulates [24]. The isolated pathogen was identified through morphological characterization according to the previous descriptions of F. oxysporum [25] and molecular analysis depending on the internal transcribed spacer (ITS) regions of rDNA.

\section{Isolation of Trichoderma}

Samples of forty-six sea muds and three algae were collected from marine habitats in three districts of Hainan Province, China: Dongfang City $\left(18^{\circ} 43^{\prime}-9^{\circ} 18^{\prime} \mathrm{N}\right.$, $\left.108^{\circ} 36^{\prime}-109^{\circ} 07^{\prime} \mathrm{E}\right)$, Sanya City $\left(18^{\circ} 09^{\prime}-18^{\circ} 37^{\prime} \mathrm{N}, 108^{\circ} 56^{\prime}-\right.$ $\left.109^{\circ} 48^{\prime} \mathrm{E}\right)$, and Lingao County $\left(19^{\circ} 34^{\prime}-20^{\circ} 02^{\prime} \mathrm{N}, 109^{\circ} 3^{\prime}-\right.$ $\left.109^{\circ} 53^{\prime} \mathrm{E}\right)$. Samples were placed in sterile polyethylene bags, stored in an icebox and transported to the laboratory as soon as possible. Trichoderma spp. were isolated from the sea mud samples using a dilution method with a modified potato dextrose agar medium (mPDA) $(200 \mathrm{~g} / \mathrm{L}$ potato, $20 \mathrm{~g} / \mathrm{L}$ glucose, $18 \mathrm{~g} / \mathrm{L}$ agar, $0.1 \mathrm{~g} / \mathrm{L}$ streptomycin, $0.3 \mathrm{~g} / \mathrm{L}$ chloramphenicol, $0.02 \mathrm{~g} / \mathrm{L}$ rose bengal) [26]. The algae samples were washed thoroughly in running tap water, then in deionized water, and cut into $10 \mathrm{~mm} \times 10 \mathrm{~mm}$ fragments with a flame-sterilized razor blade. The fragments were surface sterilized by $75 \%$ ethanol for $30 \mathrm{~s}, 8 \% \mathrm{NaClO}$ solution for $1 \mathrm{~min}$, and $75 \%$ ethanol for $30 \mathrm{~s}$, rinsed with sterile double-distilled water for five times to remove excess chemical sterilizing agents, placed on mPDA in Petri dishes, and incubated at $28^{\circ} \mathrm{C}$ for $48 \mathrm{~h}$. The putative Trichoderma isolates were selected, and purified by single spore isolation [27], then preserved at $4{ }^{\circ} \mathrm{C}$ at the Engineering Center of Agricultural Microbial Preparation Research and Development of Hainan (Hainan University) for subsequent research.

\section{Screening of Trichoderma with salt tolerance and antagonistic activity}

To assess salt tolerance, all Trichoderma isolates isolated above were cultured on PDA amended with various concentrations of $\mathrm{NaCl}(3,5,7$, and $9 \%[\mathrm{w} / \mathrm{v}])$, and incubated at $28^{\circ} \mathrm{C}$. The diameters of colonies on $\mathrm{NaCl}$-amended media were recorded on the $3 \mathrm{rd}, 5 \mathrm{th}$, and 7 th day.

To evaluate the antagonistic activity against the pathogen of cucumber root rot, all Trichoderma isolates isolated above which could grow on PDA medium containing $9 \% \mathrm{NaCl}$ and F. oxysporum HGL.1 were dual 
cultured on PDA in the presence or absence of $100 \mathrm{mM}$ $\mathrm{NaCl}$ salt stress [28]. The plates were incubated at $28^{\circ} \mathrm{C}$ for 7 days, and the radial growth radius of HGL.1 were measured.

\section{Identification of salt-tolerant Trichoderma}

The morphological and molecular identification of the Trichoderma strain showing salt tolerance and antagonistic activity were carried out. For morphological identification, hyphal morphology and colony growth patterns of salt-tolerant Trichoderma isolate were observed at 72, 96, 120,144 , and $168 \mathrm{~h}$ post inoculation on PDA, synthetic low nutrient agar (SNA: $1.0 \mathrm{~g} / \mathrm{L} \mathrm{KH}_{2} \mathrm{PO}_{4}, 10.5 \mathrm{~g} / \mathrm{L} \mathrm{KCl}$, $1.0 \mathrm{~g} / \mathrm{L} \mathrm{KNO}_{3}, 0.5 \mathrm{~g} / \mathrm{L} \mathrm{MgSO}_{4}, 0.2 \mathrm{~g} / \mathrm{L}$ dextrose, $0.2 \mathrm{~g} / \mathrm{L}$ sucrose, $18 \mathrm{~g} / \mathrm{L}$ agar), and corn meal dextrose agar (CMD: $4 \%[\mathrm{w} / \mathrm{v}]$ cornmeal $+2 \%[\mathrm{w} / \mathrm{v}]$ dextrose $+2 \%[\mathrm{w} / \mathrm{v}]$ agar) . After inoculation on SNA and CMD media for 72 and $168 \mathrm{~h}$, characteristics of the conidia, conidiophores, chlamydospores, and sori were examined and photographed under optical microscope (Olympus, BX53F) and stereoscopic microscopes (Olympus, SZX16), then compared with a published description [29].

For molecular identification, the genomic DNAs of Trichoderma isolate were extracted using the Cetyl Trimethyl Ammonium Bromide (CTAB) method as described by Stewart and Via [30] and the partial sequence of translation elongation factor 1-alpha gene (tef1) was amplified using the EF1-728F/TEF1LLErev primer pair [31]. The PCR reaction mix were as follows: $1 \times$ Green TAP Mix, $0.2 \mu \mathrm{M}$ primer EF1-728F, $0.2 \mu \mathrm{M}$ primer TEF1LLErev, $100 \mathrm{ng}$ gDNA. The tef1 PCR was performed in a 96-well PCR instrument (Hangzhou, AGS, Medtech Co., LTD). The PCR products were purified using a ZTOPO-TA Fast Cloning Kit (Zomanbio, Kit No. ZC206-1), and sequenced by Guangzhou Tianyi Huiyuan Biotechnology Co., Ltd. (Guangzhou, China). The tef1 sequences were deposited in GenBank (NCBI) to get accession number. The phylogenetic tree based on tef1 sequences were construct in MEGA-X using the Neighbour-Joining method.

\section{In vitro evaluation of antagonistic activity of salt-tolerant Trichoderma isolate against $F$. oxysporum under salt stress Dual culture and trypan blue staining}

The antagonistic activity of the salt-tolerant Trichoderma isolate against the $F$. oxysporum isolate HGL.1 was evaluated by the dual culture method as described by Morton and Stroube [28] under salt stress of $100 \mathrm{mM}$ $\mathrm{NaCl}$ or without. When cultured, the cover glasses were inserted into the dual culture plates to make the hyphae of Trichoderma and F. oxysporum grow onto them, and the plates were incubated at $28^{\circ} \mathrm{C}$. Seven days later, the radial growth radii of HGL.1 were recorded, and the interaction of hyphae on the cover glasses was observed under an optical microscope. Then mycelia in the dual culture plates were dyed using trypan blue staining method to determine whether the pathogen was killed by Trichoderma isolate [32], and the colour changing of the pathogen hypha was observed using optical microscope and photographed.

\section{Effect of volatile and non-volatile inhibitors}

The inhibitory effects of volatile and non-volatile metabolites produced by the salt-tolerant Trichoderma isolate against the . oxysporum isolate HGL.1 were evaluated by the method described by Dennis and Webster [33, 34] in the presence of $100 \mathrm{mM} \mathrm{NaCl}$ or absent. To test the effect of volatile metabolites, a cellophane sheet was sandwiched between two petri dishes on which mycelium plugs of Trichoderma and F. oxysporum were inoculated, respectively. For non-volatile metabolites, Trichoderma was cultured on cellophane covering on the medium for 2 days and then $F$. oxysporum was inoculated on the medium after the cellophane was uncovered. The cultures were incubated at $28^{\circ} \mathrm{C}$ in darkness for 7 days, and the colony radius of the pathogen was measured to calculate the inhibition ratio of mycelial growth.

\section{Effect of Trichoderma on alleviating salt stress of cucumber} Cucumber seeds (Cucumis sativus L.) of the cultivar Chuanlv 21 were surface-sterilized with $8 \% \mathrm{NaClO}$ solution for $1 \mathrm{~min}$, washed three times with distilled water, placed into distilled water for germinating, and then sown in plastic pots $(10 \mathrm{~cm}$ calibre $)$ with $0.5 \mathrm{~kg}$ composite soil (soil: sand=7:3, one plant per pot). After 10 days, seedlings of uniform size were selected and the following treatments were compared: (1) $100 \mathrm{~mL}$ water $+100 \mathrm{~mL}$ spore suspension of Trichoderma $\left(1 \times 10^{7} \mathrm{cfu} /\right.$ $\mathrm{mL}$ ) (marked as "T"); (2) $100 \mathrm{~mL}$ water $+100 \mathrm{~mL}$ water (marked as "control"); (3) $100 \mathrm{~mL} 100 \mathrm{mM} \mathrm{NaCl}$ solution $+100 \mathrm{~mL}$ spore suspension of Trichoderma $\left(1 \times 10^{7} \mathrm{cfu} / \mathrm{mL}\right) \quad$ (marked as "100S $+\mathrm{T}$ "); (4) $100 \mathrm{~mL}$ $100 \mathrm{mM} \mathrm{NaCl}$ solution $+100 \mathrm{~mL}$ water (marked as "100S"); (5) $100 \mathrm{~mL} 200 \mathrm{mM} \mathrm{NaCl}$ solution $+100 \mathrm{~mL}$ spore suspension of Trichoderma $\left(1 \times 10^{7} \mathrm{cfu} / \mathrm{mL}\right)$ (marked as "200S + T"); (6) $100 \mathrm{~mL} 200 \mathrm{mM} \mathrm{NaCl}$ solution $+100 \mathrm{~mL}$ water (marked as "200S"). All treatments were arranged in completely randomized design (CRD), and at least 30 cucumber seedlings were used for each treatment. After 14days, all the plants were harvested to measure their growth parameters and physiological-biochemical indexes.

\section{Measurement of plant growth parameters}

Twenty-one cucumber seedlings from each treatment were harvested randomly, rinsed for free of soil, and 
divided into roots and shoots. The length and fresh weight of roots and shoots were measured, and dry weights were recorded when all plant parts were dried to constant mass $\left(115^{\circ} \mathrm{C}\right.$ for $30 \mathrm{~min}$ and $80^{\circ} \mathrm{C}$ for $\left.8 \mathrm{~h}\right)$.

\section{Measurement of physiological-biochemical indexes}

Nine cucumber seedlings from each treatment were harvested randomly, and the fresh leaves were collected for measuring the content of chlorophyll $(\mathrm{Chl})$, soluble protein and malondialdehyde (MDA), and the activity of catalase (CAT) and peroxidase (POD).

The quantitative analysis of chlorophyll was done according to the method of Lichtenthaler and Wellburn [35]. The chlorophyll was extracted by acetone from $200 \mathrm{mg}$ fresh leaves and the absorbance was read at 663and 646- nm wavelength. The content of chlorophyll was calculated by the formula as follows:

$$
\begin{aligned}
& \text { Chl a }(\mathrm{mg} / \mathrm{L})=12.21 \times \mathrm{OD}_{663}-2.81 \times \mathrm{OD}_{646} \\
& \mathrm{Chl} \mathrm{b}(\mathrm{mg} / \mathrm{L})=20.13 \times \mathrm{OD}_{646}-5.03 \times \mathrm{OD}_{663} \\
& \text { Chl total }(\mathrm{mg} / \mathrm{L})=\mathrm{Chl} \mathrm{a}+\mathrm{Chl} \mathrm{b}
\end{aligned}
$$

Chl content $(\mathrm{mg} / \mathrm{g})=($ Chl . concentration $\times$ Extraction volume $\times$ dilution factor)/fresh weightLipid peroxidation was recorded in terms of concentration of malondialdehyde (MDA) by the method of Heath and Packer [36]. Absorbance at 450, 532 and $600 \mathrm{~nm}$ were used for the calculation of MDA equivalent. Blank sample was used as reference. MDA equivalent was calculated by the following equation:

MDA equivalents $(\mathrm{nmol} / \mathrm{mL})=6.45 \times\left(\mathrm{OD}_{532}-\mathrm{OD}_{600}\right)-0.56 \times \mathrm{OD}_{450}$.

The content of soluble proteins was measured according to the method described by Bradford [37]. Two hundred milligram fresh leaves were ground in sodium

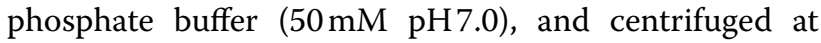
$4200 \mathrm{rpm}\left(4^{\circ} \mathrm{C}\right)$ for 10 mins. After centrifuging, the supernatant was collected in a $10 \mathrm{~mL}$ test tube, and $2 \mathrm{~mL}$ sodium phosphate buffer was added in the precipitate then centrifuged for the second time. Then mixed the supernatants and volumed to $10 \mathrm{~mL}$. The protein extract is blue when reacted with Coomassie Brilliant Blue G-250, and the absorbance of the reaction solution at the wavelength of $595 \mathrm{~nm}$ was read. Standard curve of bovine serum albumin (BSA) was used as reference.

To analyse the activities of POD and CAT, $1.0 \mathrm{~g}$ fresh leaves were ground in $25 \mathrm{~mL}$ sodium phosphate buffer $(50 \mathrm{mM} \mathrm{pH} 7.8)$ and centrifuged at $12000 \mathrm{rpm}\left(4^{\circ} \mathrm{C}\right)$ for 20 mins. The supernatant was collected to measure the activities of POD and CAT referred to the methods described by Samantary [38] and Kar and Mishra [39].

\section{Effect of Trichoderma on diminishing root rot of cucumber} Cucumber seeds (Chuanlv 21) were sown separately in plastic pots $(17 \mathrm{~cm}$ in calibre, one seed per pot) containing $2 \mathrm{~kg}$ composite soil (soil: sand =7:3, 4 plants per pot). When the third leaves emerged, one half of the seedlings were irrigated with $100 \mathrm{~mL}$ of $100 \mathrm{mM} \mathrm{NaCl}$ solution, and the other half were treated with water. The following treatments for the seedlings irrigated with salt solution or without were compared: (1) $100 \mathrm{~mL}$ spore suspension of Trichoderma $\left(1 \times 10^{7} \mathrm{cfu} / \mathrm{mL}\right)+30 \mathrm{~mL}$ spore suspension of $F$. oxysporum $\left(1 \times 10^{7} \mathrm{cfu} / \mathrm{mL}\right)$ (marked as "T-Fo"); (2) $100 \mathrm{~mL}$ water $+30 \mathrm{~mL}$ spore suspension of $F$. oxysporum $\left(1 \times 10^{7} \mathrm{cfu} / \mathrm{mL}\right)$ (marked as "Fo"); (3) $100 \mathrm{~mL}$ water $+30 \mathrm{~mL}$ water (marked as "Control"). Before inoculated by pathogen, the cucumber roots were injured by inserting transplanting shovel into soil near the plant to damage the roots. All treatments were arranged in completely randomized design, and there were at least 40 cucumber seedlings for each treatment. The disease index and control effect of all 240 cucumber seedlings were assessed on 10 days post inoculation (dpi) using the grading standard of $\mathrm{Li}$ et al. [40]:

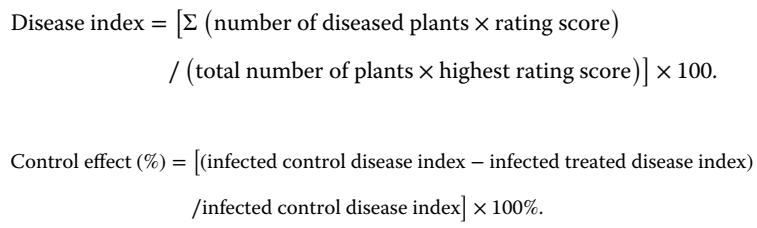

\section{Statistical analyses}

Statistical analyses of quantitative data were performed using IBM SPSS Statistics 21 software (IBM Corp, Armonk, NY, USA) and included one-way or two-way analysis of variance (ANOVA) followed by Tukey's test and Dunnett's t-test at $P<0.05$. Different superscript letters within the same column indicate statistically significant differences. All experiments were repeated at least three times.

\section{Results \\ Isolation and identification of the pathogen causing root rot in cucumber}

Ten isolates showing Fusarium-like morphological characteristics were obtained from diseased cucumber plants exhibited typical symptoms of root rot. Three isolates (HGL.1, HGL.2, and HGL.3) were randomly selected and cultured on PDA medium. The colonies of the three isolates initially showed white cotton flocculent on PDA medium and later became light red (Fig. 1A). The conidia were septate, sickle- or crescent-shaped, slightly curved 


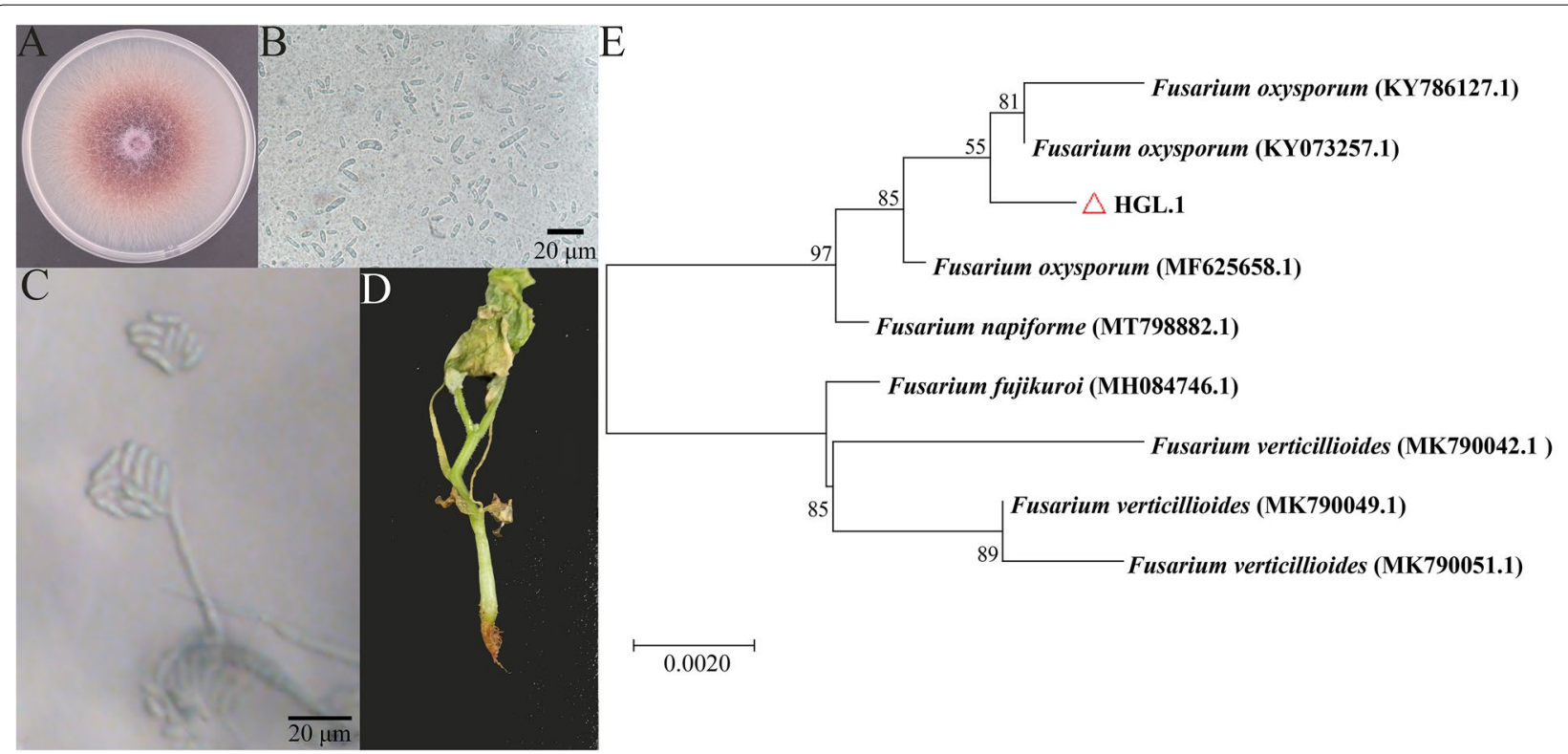

Fig. 1 Identification of causal agent HGL.1 of cucumber root rot. A Morphology of colony inoculated on PDA for 7 days. B, C Characteristics of conidia and conidiophore. D Cucumber seedling infected by isolate. E Phylogenetic tree constructed in MEGA-X using the neighbor-joining method based on ITS

or curved, and the two ends became tapered (Fig. 1B). The spores were attached to a long, tube-shaped conidiophore (Fig. 1C). These morphological features were consistent with previous descriptions of $F$. oxysporum. Pathogenicity test revealed that the plants inoculated showed rotted roots, wilted leaves and chlorosis at the leaf tips (Fig. 1D). The fungus can be re-isolated from the decaying tissue which was in accord with Koch's postulates. An rDNA-ITS fragment of $513 \mathrm{bp}$ was amplified and sequenced. The ITS sequence was deposited in GenBank and the accession number was MW091417. Phylogenetic analysis indicated that the isolate HGL.1 was closely related to F. oxysporum (GenBank Accession Nos. KY786127 and KY073257) (Fig. 1E). Therefore, the pathogen was identified as F. oxysporum.

\section{Trichoderma HN082102.1 showing salt tolerance} and antagonistic activity against F. oxysporum

Twenty-seven Trichoderma isolates were obtained from samples of 46 sea muds and 3 algae using dilution plate methods (Table 1). Among them, 27, 27, 22, and 10 isolates could grow on PDA amended with 3, 5, 7 , and $9 \%(\mathrm{w} / \mathrm{v}) \mathrm{NaCl}$, respectively. Among the 10 isolates that could grow on the medium amended with $9 \%$ $\mathrm{NaCl}, \mathrm{HN} 082102.1$ showed a particularly high level of salt tolerance, and its colony diameter was significantly bigger than others on the fifth and seventh day (Fig. 2). In addition, the isolate HN082102.1 also showed high antagonistic activity against $F$ oxysporum HGL.1 (Fig. 3). Therefore, HN082102.1 was chosen for further analysis.

Table 1 Source of Trichoderma isolates

\begin{tabular}{|c|c|c|c|}
\hline Sample & Location & Strain code & $t e f 1^{\mathrm{a}}$ \\
\hline algae & Dongfang City, Hainan Province & HN082102.1, HN082102.2 & MW133238, MW133239 \\
\hline sea muds & Dongfang City, Hainan Province & $\begin{array}{l}\text { HN082104.1, HN082104.2, HN082105.1, HN082105.2, } \\
\text { HN082106.1, HN082106.2 }\end{array}$ & $\begin{array}{l}\text { MW133240, MW133241, MW133242, MW133243, } \\
\text { MW133244, MW133245 }\end{array}$ \\
\hline sea muds & Sanya City, Hainan Province & $\begin{array}{l}\text { HN082108.2, HN082108.3, HN082108.4, HN082212.1, } \\
\text { HN082213.1, HN082213.2, HN082213.3, HN082213.4, } \\
\text { HN082213.5, HN082216.1 }\end{array}$ & $\begin{array}{l}\text { MW133246, MW133247 MW133248, MW133249, } \\
\text { MW133250, MW133251, MW133252, MW133253, } \\
\text { MW133254, MW133255 }\end{array}$ \\
\hline sea muds & Lingao City, Hainan Province & $\begin{array}{l}\text { HN082323.1, HN082325.1, HN082328, HN083003.1, } \\
\text { HN083107.1, HN083110.1, HN083111.1, HN090114.2, } \\
\text { HN090118.1 }\end{array}$ & $\begin{array}{l}\text { MW133256, MW133257, MW133258, MW133259, } \\
\text { MW133260, MW133261, MW133262, MW133263, } \\
\text { MW133264 }\end{array}$ \\
\hline
\end{tabular}

${ }^{a}$ GenBank accession numbers for translation elongation factor 1-alpha gene (tef1) partial sequence 


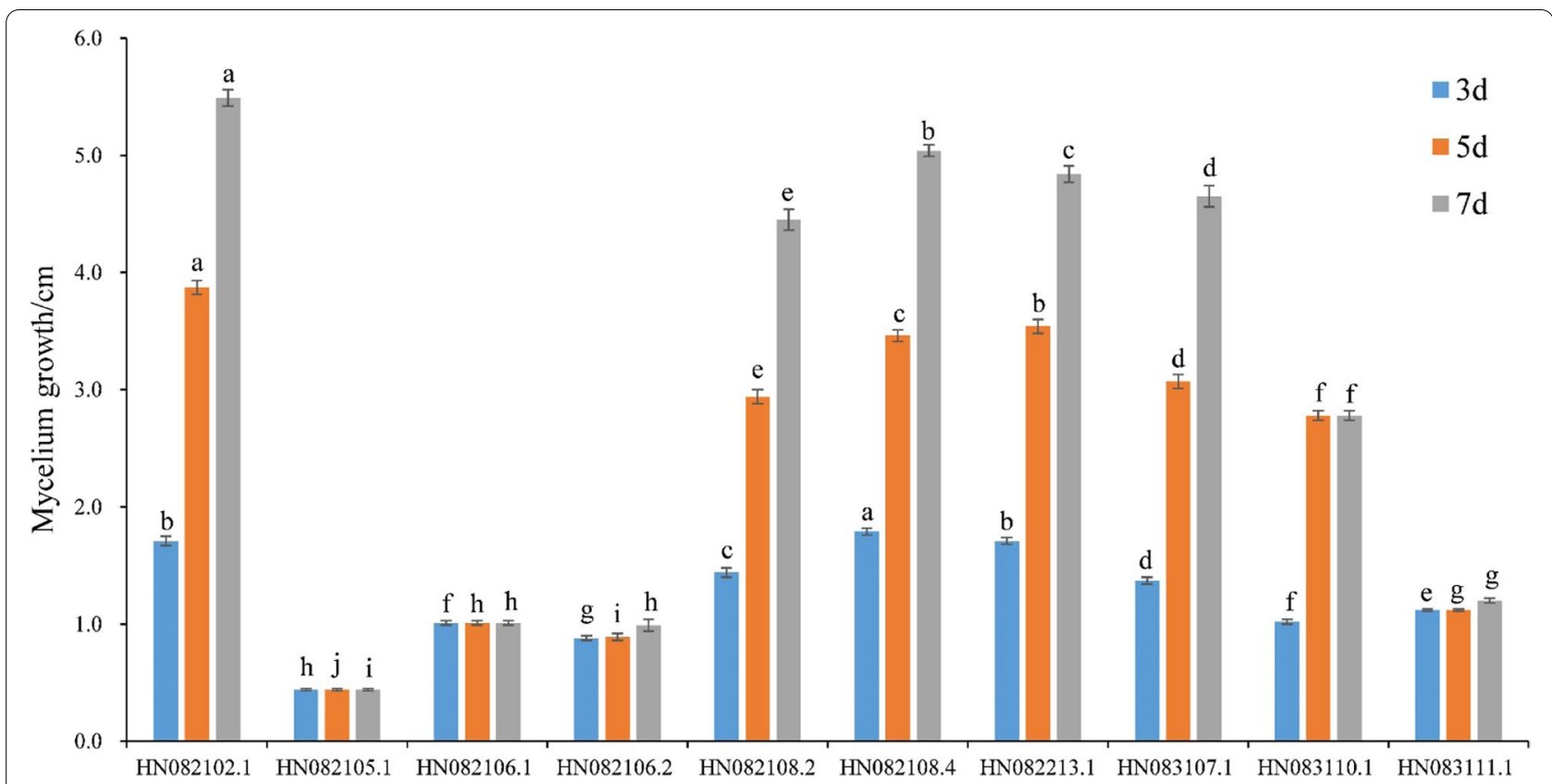

Fig. 2 Colony diameter of 10 Trichoderma isolates inoculating on PDA contained 9\% $\mathrm{NaCl}$ for 3, 5, 7 days. The lowercase letters indicate significant difference $(P<0.05)$ compared with the diameters measured on the same day

\section{Taxonomic classification of Trichoderma strain HN082102.1} The isolate HN082102.1 produced green conidia on PDA medium and smelled of a distinctive coconut odour (Fig. 4A). Yellow green sori with cotton floc were observed on CMD medium (Fig. 4B, D, E), and cyan spores were distributed in a ring on the edge of SNA medium (Fig. 4C). The conidia were subspherical to ovoid with dimensions of $2.5-3.7 \mu \mathrm{m} \times 2.9-4.6 \mu \mathrm{m}$ (Fig. $4 \mathrm{~F}$ ). The chlamydospores were abundant, globose to subglobose, and at the end or intercalary of hypha (Fig. 4G). The branches were of a pyramidal type with phialides holding in divergent whorls of three or four or arising singly near the tip of the main axis, but unilateral branches were common. Phialides were ampulliform when closely spaced, lageniform when more distantly spaced, straight or sinuous, sharply constricted at the neck when ampulliform, and 4.9-11.1 $\mu \mathrm{m}$ long and $2.1-8.5 \mu \mathrm{m}$ wide at the widest point (Fig. $4 \mathrm{H}, \mathrm{I}, \mathrm{J}$ ). These morphological characteristics were consistent with T. atroviride described by Bissett's research. Phylogenetic analysis based on tef1 sequence (accession number: MW133238) showed that isolate HN082102.1 was clustered with $T$. atroviride (HG931223.1, KT619055.1, and HG931221.1) (Fig. 4K). Therefore, isolate HN082102.1 was identified as T. atroviride.

\section{T. Atroviride HN082102.1 against F. oxysporum under salt stress}

T. atroviride HN082102.1 exhibited mycoparasitism to F. oxysporum HGL.1 causing root rot in cucumber in the presence or absence of $100 \mathrm{mM} \mathrm{NaCl}$ stress (Fig. 5A, B). The hyphae of $F$. oxysporum HGL.1 were encircled and disintegrated by T. atroviride HN082102.1 (Fig. 5B). Also, the hyphae of F. oxysporum at the interaction zone with T. atroviride were stained blue by trypan blue (Fig. $5 \mathrm{C}$ ), indicating that these hyphae were killed. At the stained areas, the unstained T. atroviride hyphae adhered or entangled to the stained F. oxysporum hyphae (Fig. 5D).

The volatile and non-volatile metabolites produced by T. atroviride inhibited significantly the mycelium growth of $F$. oxysporum, and the inhibition rates were higher than $50 \%$, even nearly $80 \%$ for non-volatile metabolites under no salt stress (Fig. 6). Interestingly, the inhibition rate of volatile metabolites to $F$. oxysporum increased by $3.00 \%$ under $100 \mathrm{mM}$ salt stress compared with the no salt control, while for the non-volatile metabolites, it decreased by 9.96\% (Fig. 6). It is suggested that salt stress may promote the inhibition effect of volatile substances to the pathogen, but show negative effect on the inhibition of non-volatile substances.

\section{T. Atroviride HN082102.1 alleviates the salt stress on cucumber growth}

The application of Trichoderma mitigated the adverse effects of salt stress and promoted the growth of cucumber under $100 \mathrm{mM}$ and $200 \mathrm{mM} \mathrm{NaCl}$, especially for the root (Fig. 7A-E). The dry weight and length of roots reduced significantly when the cucumbers grew under $100 \mathrm{mM}$ and $200 \mathrm{mM} \mathrm{NaCl}$, also for the fresh weight of roots under 


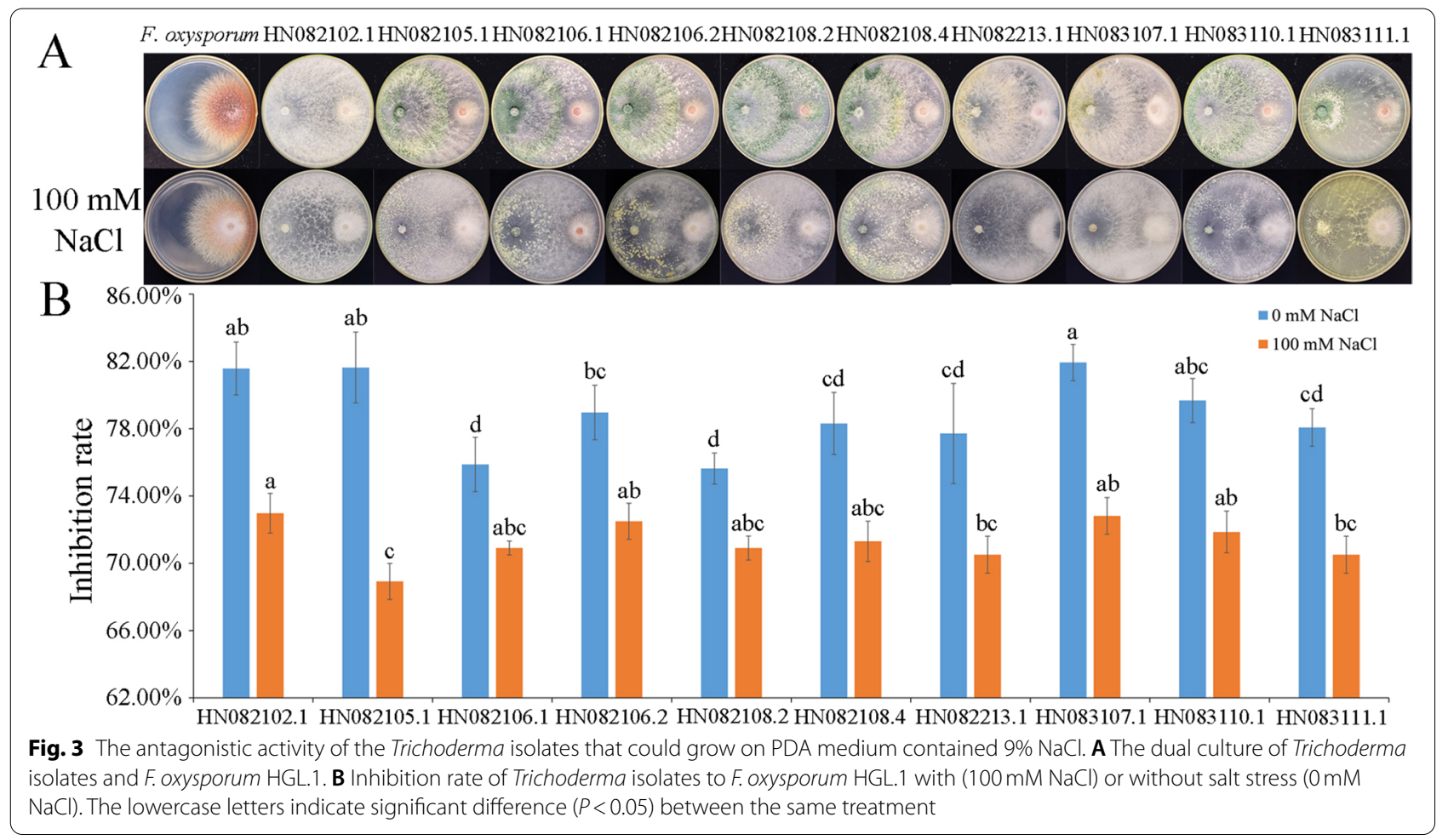

$200 \mathrm{mM} \mathrm{NaCl}$ (Fig. 7C, D, E). When cucumbers were treated with T. atroviride HN082102.1 under $100 \mathrm{mM}$ and $200 \mathrm{mM} \mathrm{NaCl}$, root fresh weight increased by 92.55 and $84.86 \%$, respectively, and root dry weight increased by 75.71 and $53.31 \%$, respectively (Fig. 7E).

With $\mathrm{NaCl}$ increased $(0,100$, and $200 \mathrm{mM})$, the total chlorophyll content of cucumber leaves decreased from $1.29 \mathrm{mgg}^{-1}$ to $1.00 \mathrm{mgg}^{-1}$. However, when T. atroviride HN082102.1 was applied, the content of total chlorophyll increased by $16.57,13.93$, and $19.68 \%$, the content of chlorophyll a increased by $14.85,14.66$, and $20.38 \%$, and the content of chlorophyll b increased by $21.80,11.93$, and $17.67 \%$ under $0 \mathrm{mM}, 100 \mathrm{mM}$ and $200 \mathrm{mM} \mathrm{NaCl}$, respectively (Fig. 7F).

The content of soluble protein of leaves decreased significantly by 21.92 and $38.26 \%$ under $100 \mathrm{mM}$ and $200 \mathrm{mM} \mathrm{NaCl}$ compared with control, and increased by 29.48 and $51.23 \%$ when Trichoderma was used under $100 \mathrm{mM}$ and $200 \mathrm{mM}$ $\mathrm{NaCl}$ (Fig. 7G). The MDA content of leaves increased by 16.40 and $39.36 \%$ under $100 \mathrm{mM}$ and $200 \mathrm{mM} \mathrm{NaCl} \mathrm{com-}$ pared with control, and decreased by 14.94 and $23.14 \%$ when Trichoderma was used under $100 \mathrm{mM}$ and $200 \mathrm{mM}$
$\mathrm{NaCl}$ (Fig. 7H). The activities of antioxidant enzymes POD and CAT increased significantly under $100 \mathrm{mM}$ and $200 \mathrm{mM}$ $\mathrm{NaCl}$ compared with control, and increased more significantly when Trichoderma was applied, which were 20.94 and $33.23 \%$ under $100 \mathrm{mM} \mathrm{NaCl}$ and 50.78 and $21.83 \%$ under $200 \mathrm{mM} \mathrm{NaCl}$ (Fig. 7I, J). This suggests that POD and CAT may help cucumber to withstand $\mathrm{NaCl}$ stress.

What's more, depending on the results above, the indexes above were not significantly different from or better than the control when T. atroviride was applied under $100 \mathrm{mM}$ $\mathrm{NaCl}$. So, $100 \mathrm{mM}$ of $\mathrm{NaCl}$ was used in the following experiment.

\section{T. Atroviride HN082102.1 diminishes root rot of cucumber}

The T. atroviride isolate HN082102.1 could control root rot of cucumber under salt stress. In Greenhouse, when seedlings were treated with T. atroviride HN082102.1, cucumber root rot caused by $F$. oxysporum was significantly inhibited (Fig. 8). The disease index of cucumber root rot decreased from 43.125 to $12.5 \%$ in non-saline soil, while decreased from 55 to $20 \%$ in $100 \mathrm{mM} \mathrm{NaCl}$ saline soil (Fig. 8C). The control effect of isolate HN082102.1 on

(See figure on next page.)

Fig. 4 Identification of the isolate HN082102.1. A-C The colony morphology of HN082102.1 grown on PDA, CMD and SNA medium, respectively. D, E The sorus morphology of HN082102.1 grown on CMD medium. F, G Morphology of the conidia and chlamydospore produced by isolate HN082102.1. H-J The conidiophores of Trichoderma isolate HN082102.1. K Neighbour-joining tree showing the evolutionary relationships of different Trichoderma species based on translation elongation factor 1 (tef 1 ) gene sequences 

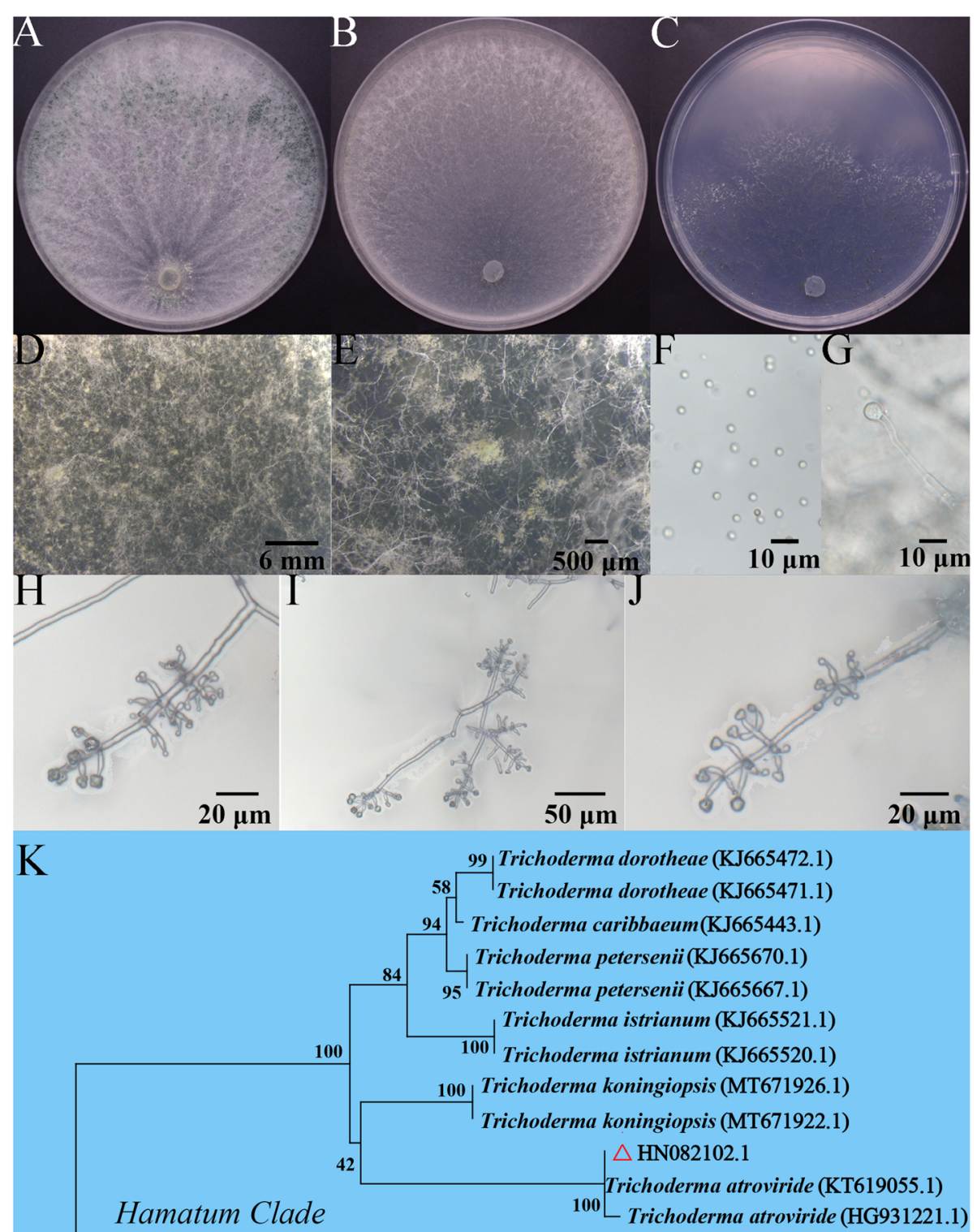

Trichoderma bissettii (HG931266.1)

100 Trichoderma bissettii (HG931264.1)

Trichoderma longibrachiatum (KF267252.1)

Longibrachiatum Clade Trichoderma longibrachiatum (MH208264.1)

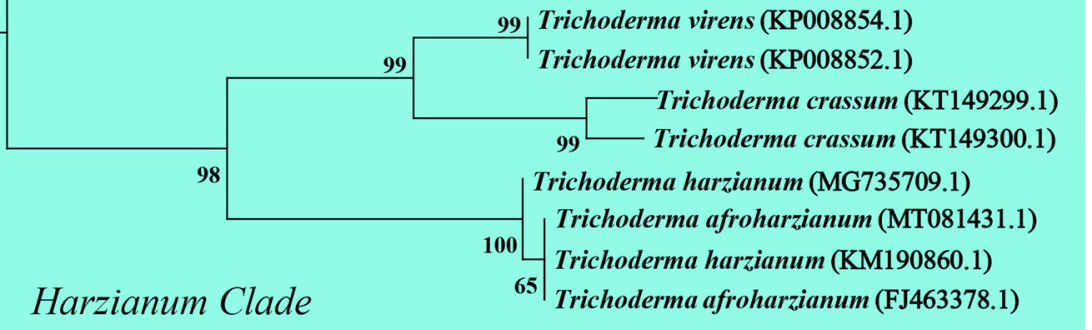

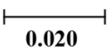

Fig. 4 (See legend on previous page.) 


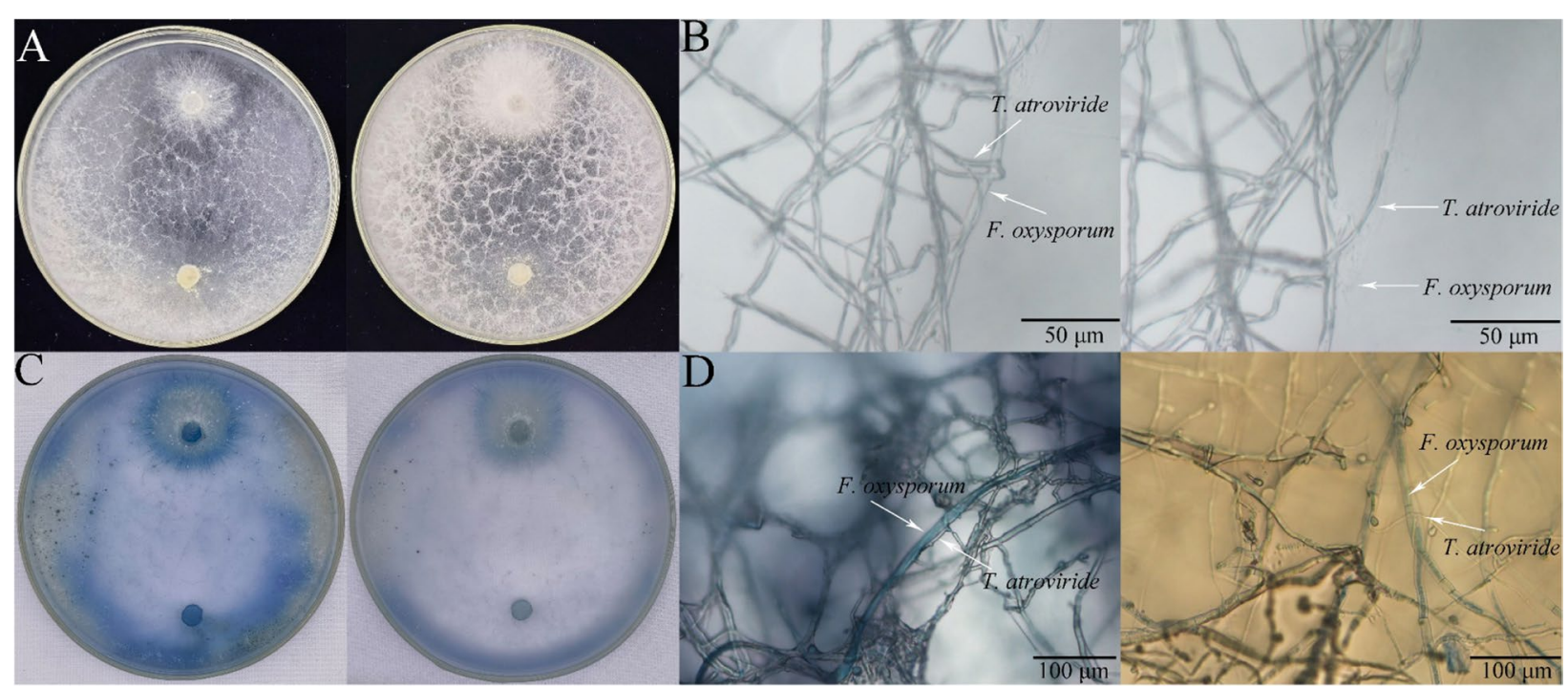

Fig. 5 The interaction zone between T. atroviride HN082102.1 and F. oxysporum HGL.1. A Dual culture of T. atroviride and F. oxysporum in the presence (right) or absence (left) of $100 \mathrm{mM} \mathrm{NaCl}$ stress. B T. atroviride hyphae encircled F. oxysporum hyphae (left) and disintegrated hypha of $F$. oxysporum (right). C Trypan blue staining of T. atroviride and F. oxysporum in the presence (right) or absence (left) of $100 \mathrm{mM} \mathrm{NaCl}$ stress. D Stained F. oxysporum hyphae

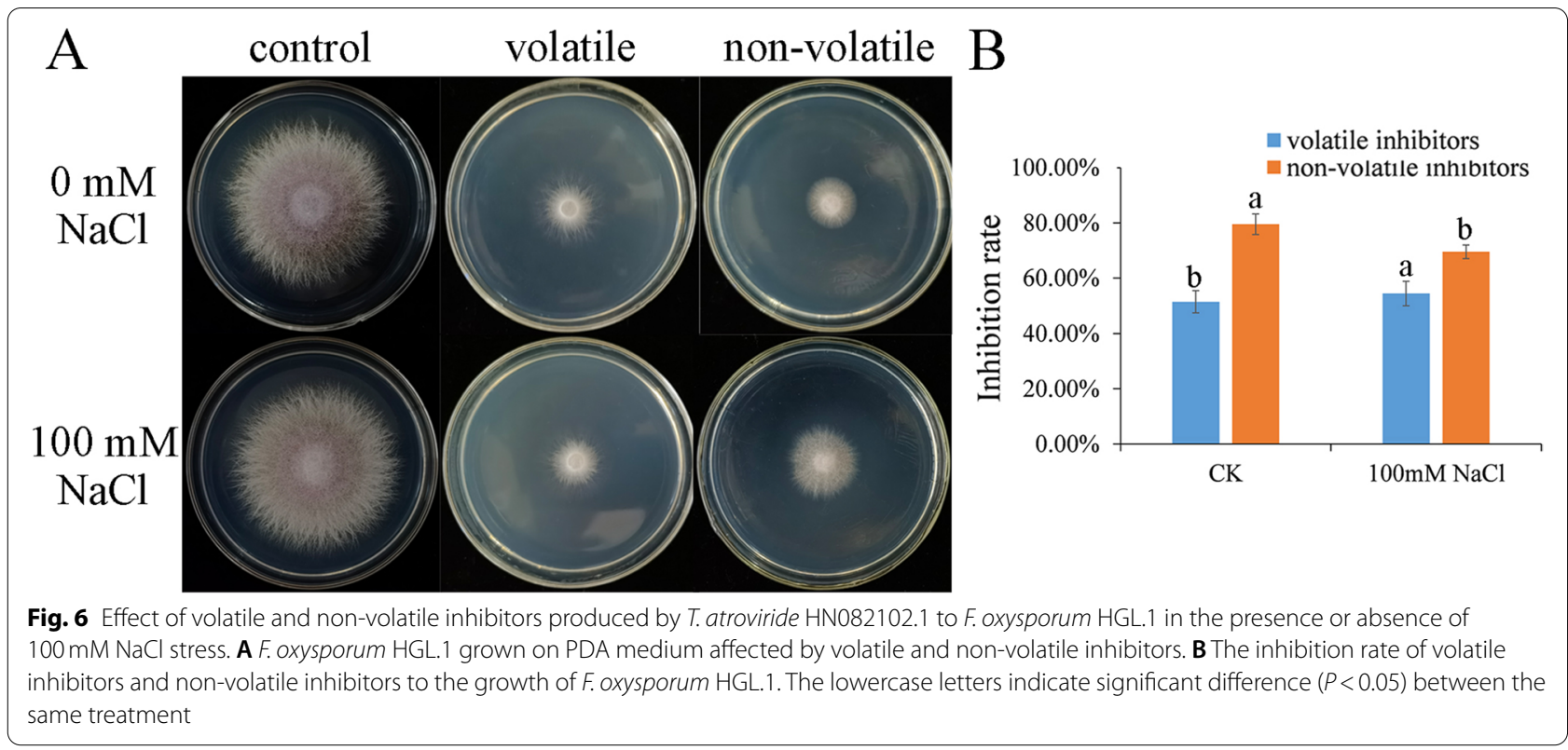

cucumber root rot was $71.01 \%$ in non-saline soil and was $63.64 \%$ in $100 \mathrm{mM} \mathrm{NaCl}$ saline soil.

\section{Discussion}

In this study, 27 Trichoderma spp. were isolated from samples of 46 sea muds and 3 algae collected from marine habitats, and the salinity resistance and antagonistic activity of these isolates were examined.
HN082102.1 isolated from algae exhibited the strongest salt tolerance and better antagonistic activity and therefore was selected to be used in the further research.

The growth parameters of cucumber, that are the length, fresh weight, and dry weight of shoots and roots, decreased significantly under $\mathrm{NaCl}$ stress, which might be attributed to increased osmotic stress, nutrient deficiencies, and disturbance of various physiological and 


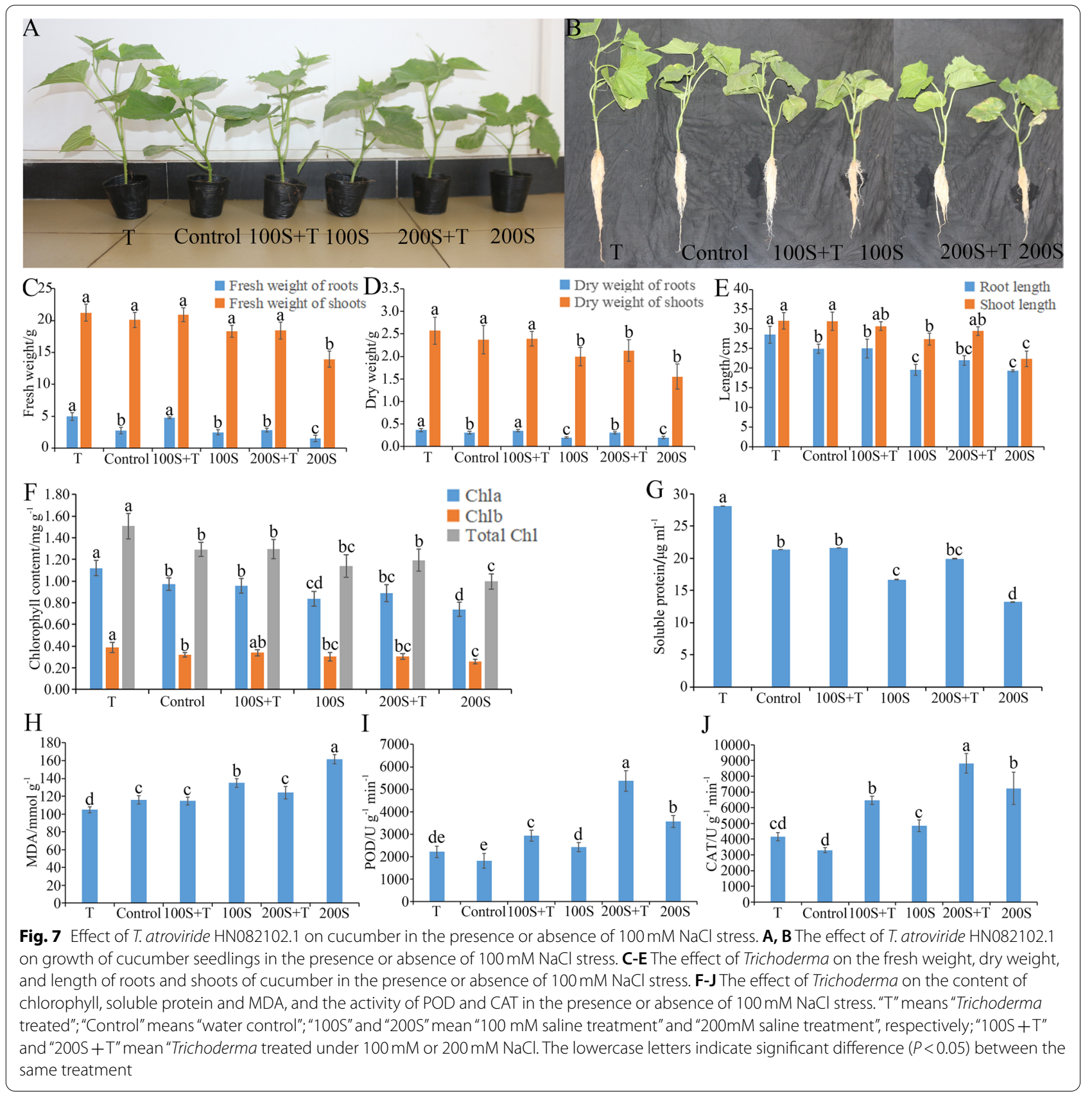

biochemical mechanisms [41-43]. When the cucumber was treated with $T$. atroviride $\mathrm{HN} 082102.1$ under $\mathrm{NaCl}$ stress, the growth parameters increased, suggesting that T. atroviride may alleviate the adverse effect of salt stress to the cucumber growth. The findings were consistent with the results of Rawat et al. [44], which reported that Trichoderma isolates alleviated the negative impacts of salt stress in rice. The application of Trichoderma increased root length of plants, thereby promoting the plant to absorb nutrients and water from the soil and enhancing its ability to counteract salt stress $[45,46]$.

The application of T. atroviride HN082102.1 significantly increased the content of chlorophyll and soluble protein and reduced the MDA content in cucumber under salt stress. Previous studies also reported the similar results [16, 47]. Zörb et al. [48] concluded that the decreased content of chlorophyll under salt stress was related to the negative effects of salt stress on 


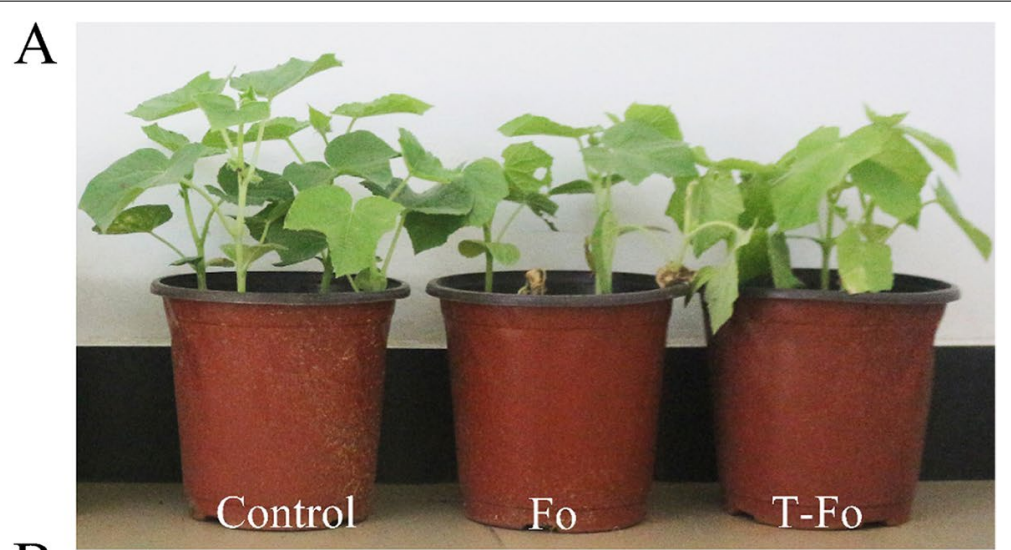

$\mathrm{B}$
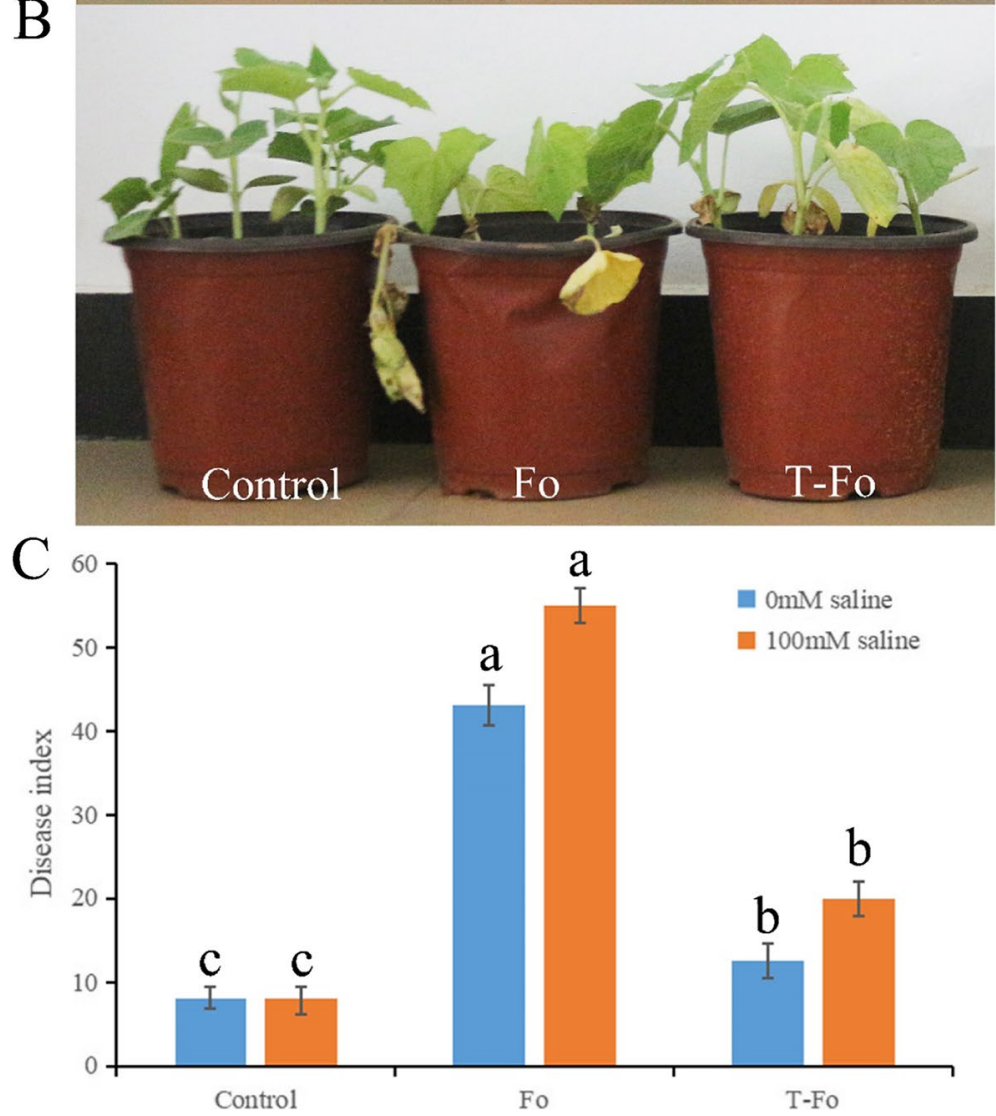

Fig. 8 Control effect of T. atroviride HN082102.1 on cucumber root rot in greenhouse in presence and absence of $100 \mathrm{mM} \mathrm{NaCl}$ stress. A The symptoms of cucumber root rot with or without the application Trichoderma in the absence of $\mathrm{NaCl}$. B The symptoms of cucumber root rot with or without the application Trichoderma in presence of $100 \mathrm{mM} \mathrm{NaCl}$ stress. CThe effect of T. atroviride HN082102.1 to disease index of cucumber root rot in presence and absence of $100 \mathrm{mM} \mathrm{NaCl}$ stress. "Control" indicated with water; "Fo" indicated infected by F. oxysporum HGL.1; "T-Fo" indicated that before infected by F. oxysporum HGL.1, treated with T. atroviride HN082102.1. Data presented are the means \pm SE. The lowercase letters indicate significant difference $(P<0.05)$ between the same treatment with two-way analysis of variance (ANOVA)

chloroplasts. Furthermore, Sultana et al. [49] demonstrated that this phenomenon was due to the increased activity of chlorophyll-degrading enzymes, thus reduced net chlorophyll synthesis. Zhao and Zhang [50] reported that the application of Trichoderma to plants under salt stress increased IAA and GA levels and decreased ABA levels. Martínez-Medina et al. [51] and Resende et al. [52] also found that plant hormones like $\mathrm{GA}, \mathrm{ABA}$, and CTK play an important role in enhancing chlorophyll content. Therefore, the increased 
content of chlorophyll associated with Trichoderma application under salt stress may be related to its effect on plant hormones. The increased soluble protein content associated with Trichoderma application was probably beneficial in reducing the osmotic potential of plant cells [53], thereby enabling the plant to absorb water from the external saline solution under salt stress. The reduction of MDA content is an important stress tolerance index, as reported in mulberry [54] and chickpea [55]. An increased MDA content reflected membrane damage caused by lipid peroxidation in the presence of ROS [56]. Exogenous application of Trichoderma reduced salt stress in cucumber, which may be attributed to reduce ROS production in treated plants.

The activity of the antioxidant enzymes POD and CAT increased under salt stress, and after the application of Trichoderma their activity increased more. To prevent the membrane damage caused by $\mathrm{O}^{2-}$ and $\mathrm{H}_{2} \mathrm{O}_{2}$, POD reduces $\mathrm{H}_{2} \mathrm{O}_{2}$ to water [57], and CAT transforms $\mathrm{H}_{2} \mathrm{O}_{2}$ to water and molecular oxygen [58]. Increased activity of antioxidant enzyme means that more ROS can be removed, thereby reducing ROS damage to plants. The application of Trichoderma increased the activity of antioxidant enzymes and was therefore conducive to scavenging more ROS produced under salt stress, thus reducing stress-related damage.

With or without salt stress, the application of T. atroviride had a significant inhibition effect on cucumber root rot, which was consistent to the reports described by Rawat et al. [59] and Kashyap et al. [13]. Singh et al. [60] demonstrated that tomato plants treated with Trichoderma obtained tolerance toward root rot by upregulating the activities of POD, polyphenol oxidase, phenylalanine ammonia lyase, and by increasing the content of total phenols. Likewise, Bae's [59] study demonstrated that phenolic glucoside levels increased significantly after the application of Trichoderma in cucumber. These results suggest that metabolites released by Trichoderma isolates not only act directly on the pathogen but also trigger the plant to release defense-related compounds. Here, it was found that the effect of isolate HN082102.1 on cucumber root rot was somewhat decreased in saline soil, which may be caused by a decline in Trichoderma metabolites. Anyway, this is the first report of salt-tolerant T. atroviride isolated from marine habitat can alleviate salt stress and diminish cucumber root rot caused by $F$. oxysporum. Taken together, T. atroviride HN082102.1 can be used as biological control agent in saline alkali land.

\section{Conclusion}

This is the first report of salt-tolerant $T$. atroviride isolated from marine habitat showing antagonistic activity to $F$. oxysporum. The application of $T$. atroviride
HN082102.1 markedly increased tolerance to salt stress and reduced the severity of root rot caused by $F$. oxysporum under saline conditions in cucumber. The increasing of ROS scavenging and maintaining the osmotic balance are key observations of the ability to tolerate salt. Therefore, T. atroviride strain HN082102.1 has the potential to improve plant growth and disease resistance serving as biological control agent in saline alkali land.

\section{Abbreviations \\ ROS: Reactive Oxygen Species; PODs: Peroxidases; ITS: Internal Transcribed Spacer; PDA: Potato Dextrose Agar; mPDA: Modified Potato Dextrose Agar; SNA: Synthetic Low Nutrient Agar; CMD: Corn Meal Dextrose; CTAB: Cetyl Trimethyl Ammonium Bromide; tef1: Translation Elongation Factor 1-Alpha gene; Chl: Chlorophyll; MDA: Malondialdehyde; CAT: Catalase; BSA: Bovine Serum Albumin}

\section{Acknowledgements}

All authors are highly grateful to the authority of the respective department and institution for their support in conducting this research.

\section{Authors' contributions}

Conceptualization, C.Z., Y.H. and T.L.; methodology, C.Z., W.W. and J.H.; software, Z.P. and Z.L.; validation, C.Z., M.X. and T.L.; formal analysis, C.Z. and Y.H.; investigation, S.R. and M.X.; resources, Z.L.; data curation, C.Z. and Z.P.; writing-original draft preparation, C.Z.; writing-review and editing, W.W. and T.L.; visualization, W.W.; supervision, T.L.; project administration, T.L.; funding acquisition, T.L. The author(s) read and approved the final manuscript.

\section{Funding}

This research was funded by Colleges and Universities Scientific Research Projects of the Education Department of Hainan Province under Grant, grant number Hnky2019ZD-4.

\section{Availability of data and materials}

Not applicable.

\section{Declarations}

\section{Ethics approval and consent to participate}

The use of plant or seed specimens and soil in the present study complies with International, National and Institutional guidelines.

\section{Consent for publication}

Not applicable.

\section{Competing interests}

The authors declare that they have no competing interests.

\section{Author details}

${ }^{1}$ Key Laboratory of Green Prevention and Control of Tropical Diseases and Pests, Hainan University, School of Plant Protection, Ministry of Education, Haikou, Hainan 570228, PR China. ${ }^{2}$ Key Laboratory of Genetics and Germplasm Innovation of Tropical Special Forest Trees and Ornamental Plants, Hainan University, Ministry of Education, Haikou, Hainan 570228, PR China. ${ }^{3}$ Key Laboratory of Germplasm Resources of Tropical Special Ornamental Plants of Hainan Province, College of Forestry, Haikou, Hainan 570228, PR China. ${ }^{4}$ Engineering Centre of Agricultural Microbial Preparation Research and Development of Hainan, Hainan University, Haikou, Hainan 570228, PR China.

Received: 28 July 2021 Accepted: 18 February 2022

Published online: 01 March 2022 


\section{References}

1. Khan MH, Panda SK. Alterations in root lipid peroxidation and antioxidative responses in two rice cultivars under $\mathrm{NaCl}$-salinity stress. Acta Physiol Plant. 2008;30(1):81. https://doi.org/10.1007/s11738-007-0093-7.

2. Munns R, Gardner PA, Tonnet ML. Growth and development in $\mathrm{NaCl}$ treated plants. II. Do Na+ or Cl-concentrations in dividing or expanding tissues determine growth in barley? Funct Plant Biol. 1988;15(4):529-40. https://doi.org/10.1071/PP9880529.

3. Muller M, Santarius KA. Changes in chloroplast membrane lipids during adaptation of barley to extreme salinity. Plant Physiol. 1978;62(3):326-9. https://doi.org/10.1104/pp.62.3.326.

4. Ahmad P, Jaleel CA, Sharma S. Antioxidant defense system, lipid peroxidation, proline-metabolizing enzymes, and biochemical activities in two Morus alba genotypes subjected to $\mathrm{NaCl}$ stress. Russ J Plant Physiol. 2010:57(4):509-17. https://doi.org/10.1080/110241502321116514.

5. Moran JF, Becana M, Iturbe-Ormaetxe I, Frechilla S, Klucas RV, Aparicio-Tejo P. Drought induces oxidative stress in pea plants. Planta. 1994;194(3):346-52. https://doi.org/10.1007/BF00197534.

6. Dileo MV, Pye MF, Roubtsova TV, Duniway JM, Macdonald JD, Rizzo DM, et al. Abscisic acid in salt stress predisposition to phytophthora root and crown rot in tomato and chrysanthemum. Phytopathology. 2010;100(9):871-9. https://doi.org/10.1094/PHYTO-100-9-0871.

7. Triky-Dotan S, Yermiyahu U, Katan J, Gamliel A. Development of crown and root rot disease of tomato under irrigation with saline water. Phytopathology. 2005;95(12):1438-44. https://doi.org/10.1094/PHYTO-95-1438.

8. Mahajan M, Yadav SK. Overexpression of a tea flavanone 3-hydroxylase gene confers tolerance to salt stress and Alternaria solani in transgenic tobacco. Plant Mol Biol. 2014;85(6):551-73. https://doi.org/10.1007/ s11103-014-0203-z.

9. Shahid SA, Zaman M, Heng L. Soil salinity: historical perspectives and a world overview of the problem. In: Guideline for salinity assessment, mitigation and adaptation using nuclear and related techniques. Cham: Springer; 2018

10. Spadaro D, Gullino ML. Improving the efficacy of biocontrol agents against soilborne pathogens. Crop Prot. 2005;24(7):601-13. https://doi. org/10.1016/j.cropro.2004.11.003.

11. Washington WS, Mcgee P. Dimethomorph soil and seed treatment of potted tomatoes for control of damping-off and root rot caused by Phytophthora nicotianae var. nicotianae. Australas Plant Pathol. 2000;29(1):46-51. https://doi.org/10.1071/AP00007.

12. Brady NC, Weil RR. The nature and properties of soils. New York: The nature and properties of soils; 1960.

13. Kashyap PL, Solanki MK, Kushwaha P, Kumar S, Srivastava AK. Biocontrol potential of salt-tolerant Trichoderma and Hypocrea isolates for the Management of Tomato Root rot under Saline Environment. J Soil Sci Plant Nutr. 2020;20(1):160-76. https://doi.org/10.1007/s42729-019-00114-y.

14. Mukherjee PK, Horwitz BA, Singh US, Mukherjee M, Schmoll M. Trichoderma: biology and applications. India: CABl; 2013.

15. Tomico-Cuenca I, Mach RL, Mach-Aigner AR, Derntl C. An overview on current molecular tools for heterologous gene expression in Trichoderma. Fungal Biol Biotechnol. 2021;8(1):11. https://doi.org/10.1186/ s40694-021-00119-2.

16. Hashem A, Abd_Allah EF, Alqarawi AA, Huqail A, Egamberdieva D. Alleviation of abiotic salt stress in Ochradenus baccatus (Del.) by Trichoderma hamatum (Bonord). Bainier J Plant Interact. 2014;9(1). https://doi.org/10. 1080/17429145.2014.983568.

17. Hermosa R, Viterbo A, Chet I, Monte E. Plant-beneficial effects of Trichoderma and of its genes. Microbiology. 2012;158(Pt 1):17-25. https://doi. org/10.1099/mic.0.052274-0.

18. Zhang C, Wang W, Xue M, Liu Z, Zhang Q, Hou J, et al. The combination of a biocontrol agent Trichoderma asperellum SC012 and Hymexazol reduces the effective fungicide dose to control Fusarium wilt in cowpea. J Fungi (Basel, Switzerland). 2021;7(9). https://doi.org/10.3390/jof7090685.

19. Dugassa A, Alemu T, Woldehawariat Y. In-vitro compatibility assay of indigenous Trichoderma and Pseudomonas species and their antagonistic activities against black root rot disease (Fusarium solani) of faba bean (Vicia faba L.). BMC Microbiol. 2021;21(1):115. https://doi.org/10. 1186/s12866-021-02181-7.

20. Harman GE, Howell CR, Viterbo A, Chet I, Lorito M. Trichoderma species - opportunistic, avirulent plant symbionts. Nat Rev Microbiol. 2004;2(1):43-56. https://doi.org/10.1038/nrmicro797.
21. Gachomo EW. The use of Trichoderma harzianum and T. viride as potential biocontrol agents against Peanut microflora and their effectiveness in reducing Aflatoxin contamination of infected kernels. Biotechnology. 2008;7(3). https://doi.org/10.3923/biotech.2008.439.447.

22. Shoresh M, Harman GE, Mastouri F. Induced systemic resistance and plant responses to fungal biocontrol agents. Annu Rev Phytopathol. 2010;48(1):21-43. https://doi.org/10.1146/annurev-phyto-073009-114450.

23. La Spada F, Stracquadanio C, Riolo M, Pane A, Cacciola SO. Trichoderma counteracts the challenge of Phytophthora nicotianae infections on tomato by modulating plant defense mechanisms and the expression of Crinkler, necrosis-inducing Phytophthora protein 1, and cellulose-binding elicitor Lectin pathogenic effectors. Front Plant Sci. 2020;11:583539. https://doi.org/10.3389/fpls.2020.583539.

24. Summerell BA, Salleh B, Leslie JF. A utilitarian approach to Fusarium identification. Plant Dis. 2003;87(2):117-28. https://doi.org/10.1094/ PDIS.2003.87.2.117.

25. Vakalounakis DJ. Root and stem rot of cucumber caused by Fusarium oxysporum f. sp. radicis-cucumerinum f. sp. nov. Plant Dis. 1996;80(3):313. https://doi.org/10.1094/PD-80-0313.

26. Gil SV, Pastor S, March GJ. Quantitative isolation of biocontrol agents Trichoderma spp., Gliocladium spp. and Actinomycetes from soil with culture media. Microbiol Res. 2009;164(2):196-205. https://doi.org/10. 1016/j.micres.2006.11.022.

27. Dou K, Gao J, Zhang C, Yang H, Chen J. Trichoderma biodiversity in major ecological systems of China. J Microbiol. 2019. https://doi.org/ 10.1007/s12275-019-8357-7.

28. Morton DT, Stroube NH. Antagonistic and stimulatory effects of microorganisms upon Sclerotium rolfsii. Phytopathology. 1955;45:419-20.

29. Bissett J. Trichoderma atroviride. Canjbot. 1992;70(70):639-41. https:// doi.org/10.1139/b92-082.

30. Stewart C, Via LE. A rapid CTAB DNA isolation technique useful for RAPD fingerprinting and other PCR applications. Biotechniques. 1993:14(5):748-50

31. Druzhinina IS, Kopchinskiy AG, Komoń M, Bissett J, Szakacs G, Kubicek CP. An oligonucleotide barcode for species identification in Trichoderma and Hypocrea. Fungal Genet Biol. 2005;42(10):813-28. https:// doi.org/10.1016/j.fgb.2005.06.007.

32. Strober W. Trypan blue exclusion test of cell viability. Curr Protoc Immunol. 2001;Appendix 3:Appendix 3B. https://doi.org/10.1002/ 0471142735.ima03bs21.

33. De nnis C, Webster J. Antagonistic properties of species-groups of Trichoderma: I. production of non-volatile antibiotics. Trans Br Mycol Soc. 1971. https://doi.org/10.1016/S0007-1536(71)80077-3.

34. De nnis C, Webster J. Antagonistic properties of species-groups of Trichoderma: II. Production of volatile antibiotics. Trans Br Mycol Soc. 1971. https://doi.org/10.1016/S0007-1536(71)80078-5.

35. Lichtenthaler HK, Wellburn AR. Determinations of total carotenoids and chlorophylls a and b of leaf extracts in different solvents. Analysis. 1983;11(5):591-2. https://doi.org/10.1042/bst0110591.

36. Heath RL, Packer L. Photoperoxidation in isolated chloroplasts: I. kinetics and stoichiometry of fatty acid peroxidation. Arch Biochem Biophys. 1968;125(1):189-98. https://doi.org/10.1016/0003-9861(68)90654-1.

37. Bradford MM. A rapid and sensitive method for the quantitation of microgram quantities of protein utilizing the principle of protein-dye binding. Anal Biochem. 1976;72(1):248-54. https://doi.org/10.1016/ 0003-2697(76)90527-3.

38. Samantary S. Biochemical responses of $\mathrm{Cr}$-tolerant and $\mathrm{Cr}$-sensitive mung bean cultivars grown on varying levels of chromium. Chemosphere. 2002;47(10):1065-72. https://doi.org/10.1016/S0045-6535(02)00091-7.

39. Kar M, Mishra D. Catalase, peroxidase, and Polyphenoloxidase activities during Rice leaf senescence. Plant Physiol. 1976;57(2):315-9. https://doi. org/10.1104/pp.57.2.315.

40. Li BJ, Liu Y, Shi YX, Xie XW, Guo YL. First report of crown rot of grafted cucumber caused by Fusarium solani in China. Plant Dis. 2010;94(11):1377. https://doi.org/10.1094/PDIS-03-10-0217.

41. Iqbal M, Ashraf M. Alleviation of salinity-induced perturbations in ionic and hormonal concentrations in spring wheat through seed preconditioning in synthetic auxins. Acta Physiol Plant. 2013;35(4):1093-112. https://doi.org/10.1007/s11738-012-1147-z.

42. Rasool S, Ahmad A, Siddiqi TO, Ahmad P. Changes in growth, lipid peroxidation and some key antioxidant enzymes in chickpea genotypes 
under salt stress. Acta Physiol Plant. 2013;35(4):1039-50. https://doi.org/ 10.1007/s11738-012-1142-4

43. Alqarawi AA, Hashem A, Abd Allah EF, Alshahrani TS, Huqail AA. Effect of salinity on moisture content, pigment system, and lipid composition in Ephedra alata Decne. Acta Biol Hung. 2014;65(1):61-71. https://doi.org/ 10.1556/ABiol.65.2014.1.6.

44. Rawat L, Singh Y, Shukla N, Kumar J. Seed biopriming with salinity tolerant isolates of Trichoderma harzianum alleviates salt stress in rice: growth, physiological and biochemical characteristics. J Plant Pathol. 2012;94(2):353-65. https://doi.org/10.4454/JPP.FA.2012.026.

45. Arora DK, Elander RP, Mulerji KG. Fungal biotechnology. New York: Marcel Dekker; 1992.

46. He C, Wang W, Hou J. Plant performance of enhancing licorice with dual inoculating dark septate endophytes and Trichoderma viride mediated via effects on root development. BMC Plant Biol. 2020;20(1):325. https:// doi.org/10.1186/s12870-020-02535-9.

47. Zhang F, Wang Y, Liu C, Chen F, Ge H, Tian F, et al. Trichoderma harzianum mitigates salt stress in cucumber via multiple responses. Ecotoxicol Environ Saf. 2019;170:436-45. https://doi.org/10.1016/j.ecoenv.2018.11.084.

48. Zörb C, Herbst R, Forreiter C, Schubert S. Short-term effects of salt exposure on the maize chloroplast protein pattern. Proteomics. 2009:9(17):4209-20. https://doi.org/10.1002/pmic.200800791.

49. Sultana $\mathrm{N}$, Ikeda T, Itoh R. Effect of $\mathrm{NaCl}$ salinity on photosynthesis and dry matter accumulation in developing rice grains. Environ Exp Bot. 1999;42(3):211-20. https://doi.org/10.1016/S0098-8472(99)00035-0.

50. Zhao L, Zhang Y-q. Effects of phosphate solubilization and phytohormone production of Trichoderma asperellum Q1 on promoting cucumber growth under salt stress. Journal of integrative. Agriculture. 2015;14(8):1588-97. https://doi.org/10.1016/S2095-3119(14)60966-7.

51. Martínez-Medina A, Del Mar AM, Pascual JA, Van Wees SCM. Phytohormone profiles induced by Trichoderma isolates correspond with their biocontrol and plant growth-promoting activity on melon plants. J Chem Ecol. 2014;40(7):804-15. https://doi.org/10.1007/s10886-014-0478-1.

52. Mara PR, Isabel C, Luiz C, Marcos AS, Flvia DP, Edson LS, et al. Phosphate solubilization and phytohormone production by endophytic and rhizosphere Trichoderma isolates of guanandi (Calophyllum brasiliense Cambess). Afr J Microbiol Res. 2014;8(27):2616.

53. Doganlar ZB, Demir K, Basak H, Gul I. Effects of salt stress on pigment and total soluble protein contents of three different tomato cultivars. Afr J Agric Res. 2010;15(15). https://doi.org/10.1021/jf1012242.

54. Ahmad P, Umar S, Sharma S. Mechanism of free radical scavenging and role of Phytohormones in plants under abiotic stresses. Plant Adapt Phytoremed. 2010:99-118. https://doi.org/10.1007/978-90-481-9370-7_5.

55. Rasool S, Hameed A, Azooz MM, Rehman MU, Ahmad P. Salt stress: causes, types and responses of plants. In: Ecophysiology and responses of plants under salt stress. New York: Springer LLC; 2013.

56. Montillet J-L, Chamnongpol S, Rustérucci C, Dat J, van de Cotte B, Agnel $J-\mathrm{P}$, et al. Fatty acid Hydroperoxides and $\mathrm{H}_{2} \mathrm{O} 2$ in the execution of hypersensitive cell death in tobacco leaves. Plant Physiol. 2005;138(3):1516-26. https://doi.org/10.1104/pp.105.059907.

57. Wang W-B, Kim Y-H, Lee H-S, Kim K-Y, Deng X-P, Kwak S-S. Analysis of antioxidant enzyme activity during germination of alfalfa under salt and drought stresses. Plant Physiol Biochem. 2009;47(7):570-7. https://doi. org/10.1016/j.plaphy.2009.02.009.

58. Wu Z, Zhao X, Sun X, Tan Q, Tang Y, Nie Z, et al. Antioxidant enzyme systems and the ascorbate-glutathione cycle as contributing factors to cadmium accumulation and tolerance in two oilseed rape cultivars (Brassica napus L.) under moderate cadmium stress. Chemosphere. 2015;138:526-36. https://doi.org/10.1016/j.chemosphere.2015.06.080

59. Bae H, Roberts DP, Lim HS, Strem MD, Park SC, Ryu CM, et al. Endophytic Trichoderma isolates from tropical environments delay disease onset and induce resistance against Phytophthora capsici in hot pepper using multiple mechanisms. Mol Plant-Microbe Interact. 2011;24(3):336-51. https://doi.org/10.1094/mpmi-09-10-0221.

60. Singh BN, Singh A, Singh BR, Singh HB. Trichoderma harzianum elicits induced resistance in sunflower challenged by Rhizoctonia solani. J Appl Microbiol. 2014;116(3):654-66. https://doi.org/10.1111/jam.12387.

\section{Publisher's Note}

Springer Nature remains neutral with regard to jurisdictional claims in published maps and institutional affiliations.
Ready to submit your research? Choose BMC and benefit from:

- fast, convenient online submission

- thorough peer review by experienced researchers in your field

- rapid publication on acceptance

- support for research data, including large and complex data types

- gold Open Access which fosters wider collaboration and increased citations

- maximum visibility for your research: over $100 \mathrm{M}$ website views per year

At BMC, research is always in progress.

Learn more biomedcentral.com/submissions 